\title{
Zastosowanie modelu SIPOC i macierzy RACI w analizie biznesowej operatora logistycznego
}

\author{
Application of the SIPOC model and the RACI matrix in the \\ logistic operator's business analysis
}

\begin{abstract}
Streszczenie:
Głównym celem artykułu jest przedstawienie sposobu podejścia do analizy biznesowej organizacji z wykorzystaniem modelu SIPOC i macierzy RACI. Cele szczegółowe obejmują przedstawienie istoty i celów analizy biznesowej oraz założeń prezentowanego modelu i macierzy, mogących służyć nie tylko do opisu procesów, ale także do analizy wartości kreowanej przez poszczególne zadania z perspektywy całego procesu biznesowego. Prezentowane podejście przedstawiono w oparciu o przypadek operatora logistycznego planującego wdrożenie kompleksowego wsparcia IT dla logistyki.
\end{abstract}

Słowa kluczowe: analiza biznesowa, proces biznesowy, model SIPOC, macierz RACI, operator logistyczny

\begin{abstract}
:
The main goal of this article is to present the approach to the organization business analysis made with the use of the SIPOC model and the RACI matrix. The detailed objectives include presentation of the essence and goals of business analysis and the assumptions of the presented model and matrix that can be applied not only to describe processes but also to analyse the value created by individual tasks from the perspective of the entire business process. The discussed approach is based on the case of a logistics operator planning to comprehensive IT support for logistics.
\end{abstract}

Keywords: business process, business process, SIPOC model, RACI matrix, logistic operator 
Konrad Michalski - Zastosowanie modelu SIPOC...

\section{Wprowadzenie}

Etap przygotowania każdej zmiany w organizacji jest kluczowy dla jej powodzenia. Wdrożenie kompleksowego systemu IT wspierającego realizację celów organizacji jest wyzwaniem wymagającym od organizacji gruntownego przygotowania. Kluczowym krokiem w tym procesie jest identyfikacja potrzeb $\mathrm{w}$ zakresie funkcji spełnianych przez przyszłe rozwiązanie i przypisanie szczegółowych zadań konkretnym użytkownikom planowanego wdrożenia. Tymczasem, na co wskazuje praktyka działania, potrzeby organizacji nie są identyfikowane w pełni, nie są identyfikowane prawidłowo albo pozostają nieujawnione. Odpowiednio przeprowadzony proces analizy biznesowej pozwala na kompleksowe podejście do poznania klienta, jakim jest organizacja i jej potrzeb, rozumianych, jako przyszłe wymogi względem projektowanego wsparcia IT. Takie traktowanie analizy biznesowej zwiększa szanse powodzenia wdrożenia rozwiązania informatycznego, rozumianego jako wprowadzenie do organizacji systemu najbardziej dopasowanego do jej potrzeb i co równie istotne, realnie wspierającego cele całej organizacji. Podejście takie nie gwarantuje sukcesu - to gorzka prawda wynikająca z praktyki biznesowej, ale z drugiej strony, brak takiego podejścia drastycznie może obniżyć szanse na powodzenie wdrożenia.

\section{Istota i cele analizy biznesowej}

Analiza biznesowa to sformalizowana analiza systemowa organizacji i powiązanych z nią podmiotów biznesowych, prowadzona w celu stworzenia modelu ich funkcjonowania i zrozumienia zasad działania. Analiza biznesowa bardzo często prowadzona jest w celu oceny wpływu planowanych zmian i wyspecyfikowania wymagań w stosunku do planowanego rozwiązania, w szczególności technologii informacyjnych i informatycznych ${ }^{1}$. s. 17.

${ }^{1}$ J. Żeliński, Analiza biznesowa. Praktyczne modelowanie organizacji, Gliwice 2017, 
Analiza biznesowa organizacji jest niezbędnym etapem wdrożenia jakiegokolwiek kompleksowego rozwiązania IT, przeprowadzanym w celu uniknięcia, a przynajmniej minimalizacji, sytuacji typu:

- nie dostarczono nic - projekt został zarzucony przez klienta (organizację) w trakcie wdrożenia lub niedokończony przez wdrażającego (własna sfera IT organizacji, podmiot wdrażający, trzeci partner - tzw. integrator),

- dostarczono to, co chciał klient, ale niekoniecznie to, czego w rzeczywistości potrzebował (w rezultacie IT nie wspiera realizacji celów organizacji, a korzyści ograniczone są do sfery funkcjonalnej, np. logistyki),

- projekt został wdrożony, ale ludzie pracują „po staremu” (w ogóle bez wykorzystania IT lub też w ograniczonym zakresie),

- po wdrożeniu pogorszyły się procesy biznesowe, obsługowe, np. logistyczne, wspierające, np. księgowe, współpraca między jednostkami, a w konsekwencji wyniki całej organizacji).

Jak wskazują klienci IT, błędy na etapie planowania wdrożenia są kosztowne2:

- błędy w wymaganiach to jedna trzecia wszystkich defektów w projektach,

- procesy związane ze zbieraniem wymagań są źródłem większości poważnych problemów z jakością,

- zmiany zakresu są jednym z najczęstszych źródeł dodatkowych kosztów w projektach i prowadzą do porzucenia projektu,

- naprawa błędów związanych z wymaganiami pochłania 70-80\% kosztów ponownej pracy w projektach IT, a całkowite koszty ponownej pracy zjadają nawet do $50 \%$ kosztów projektu,

- szukanie i naprawianie błędów wymagań po wdrożeniu systemu jest 100 razy kosztowniejsze niż szukanie i naprawianie tych samych błędów podczas zbierania wymagań.

\footnotetext{
2 Ibidem, s. 8-9.
} 
Konrad Michalski - Zastosowanie modelu SIPOC...

Jak należy traktować, w praktyce, analizę biznesową organizacji, w kontekście wdrożenia kompleksowego rozwiązania IT? Analiza ta powinna być procesem poznania całej organizacji i realizowanych przez nią wszystkich procesów, także tych na styku z klientem zewnętrznym i partnerami, np. w łańcuchu logistycznym. Analiza biznesowa powinna być oparta na wspólnej (tj. zlecającego klienta i realizującej zlecenie) identyfikacji potrzeb w zakresie wsparcia IT, skutkującej specyfikacją wymagań dla systemu. Identyfikacja potrzeb w zakresie IT, powinna wychodzić z analizy potrzeb całej organizacji w zakresie realizowanych celów biznesowych czy innych. Jednocześnie, rezultatem analizy biznesowej powinny być też postulaty ewentualnych zmian w funkcjonowaniu organizacji i jej procesów, tak, aby maksymalnie wykorzystać możliwości stworzone dzięki wsparciu IT.

Analiza biznesowa organizacji może zawierać następujące etapy:

- definicję roli organizacji na rynku, zrozumienie i opisanie wartości użytkowej, jaką wnoszą oferowane produkty dla klienta końcowego organizacji,

- opisanie procesu powstawania produktów z punktu widzenia generowanej wartości dla klienta końcowego - zbudowanie modelu organizacji w postaci, np. mapy procesów,

- ocenę - na podstawie modelu organizacji - struktury organizacyjnej w zakresie tego, czy i jak wspiera ona procesy zachodzące w organizacji.

\section{Transformacyjny charakter procesu biznesowego}

Próba spojrzenia na termin „proces” pozwala, zauważyć, że wśród jego definicji pojawiają się te o charakterze transformacyjnym, będącym założeniem, że proces to zbiór działań przekształcających będące na wejściu nakłady w oczekiwane na wyjściu z procesu wartości, pożądane przez klienta ${ }^{3}$. Inna, tego samego rodzaju, definicja procesu stanowi, że proces to specyficzna forma zamawiania czynności pracy

\footnotetext{
${ }^{3}$ M. Hammer, J. Champy, Reeingeering w przedsiębiorstwie, Warszawa 1996, s. 49.
} 
w czasie i przestrzeni, z określonym początkiem i końcem oraz jasno określonym wejściem i wyjściem ${ }^{4}$. Wymóg tego, by kompleksowe opracowanie zadań w układzie nakład - efekt (input-output), charakteryzowało się powiększeniem wartości wytworzonej na wyjściu z procesu w stosunku do nakładów wejściowych, jest wyrazem proefektywnościowego podejścia do procesu ${ }^{5}$. Jeszcze inne rozumienie procesu również oparte na zjawisku transformacji - odwołuje się natomiast do funkcji zadania, odniesionego do konkretnego obiektu, celem otrzymania konkretnego rezultatu, którym będzie przejście obiektu z jednego stanu w drugi 6 . Obiektem może być - w myśl tej definicji - produkt materialny w kolejnym stadium jego wytwarzania lub usługa, będąca przedmiotem transakcji, czyli także swego rodzaju przekształceniem.

Analiza biznesowa organizacji opiera się na założeniu o konieczności identyfikacji wszystkich aktywności przyczyniających się do stałego dostarczania przez nią wartości pożądanych przez odbiorcę jej produktów. Poprzez wartość dostarczaną klientowi należy rozumieć te walory, cechy, korzyści itd., które charakteryzują oferowany produkt, a dzięki którym klient decyduje się na jego zakup, czyli de facto płaci oferentowi. Odnosząc się do usługi logistycznej dla klienta biznesowego (prowadzącego swoją działalność gospodarczą), czyli produktu dostarczanego na rynek TSL (transport, spedycja, logistyka), najważniejszymi wartościami dla klienta tej usługi jest wsparcie prowadzonej przez niego działalności, dzięki:

- elastyczności w podejściu do sposobu zaspokojenia potrzeb, poprzez propozycję projektu usługi, wspólnie wypracowaną i wdrożoną,

- wiarygodności w realizacji uzgodnionych standardów jakości,

- niezawodności obsługi,

- partnerskich relacji i komunikacji.

\footnotetext{
${ }^{4}$ T. H. Davenport, Process Innovation: Reengineering Work through Information Technology, Boston 1993, s. 5.

${ }^{5}$ E. Skrzypek, Jakość i efektywność, Lublin 2002, s. 146.

${ }^{6}$ M. Chaberek, Logistyka informacji zarządczej $w$ kontrolingu przedsiębiorstwa, Gdańsk 2001, s. 59.
} 
Konrad Michalski - Zastosowanie modelu SIPOC...

Jeżeli pojęcie wartości potraktujemy jako wyznacznik wszelkich działań organizacji to poprzez proces biznesowy powinno rozumieć się zbiór aktywności organizacji, realizowanych także w relacjach z jej otoczeniem, przyczyniających się do dostarczania pożądanych wartości dla klienta, przy czym nośnikiem tych wartości jest końcowy produkt. Proces biznesowy zaczyna się i kończy u klienta7 .

Aby przeprowadzić jakąkolwiek analizę biznesową potrzebny jest model funkcjonowania organizacji w postaci, np. mapy procesów (Rys. 1), będącej punktem wyjścia dalszych działań.

Rys. 1. Organizacja jako system procesów

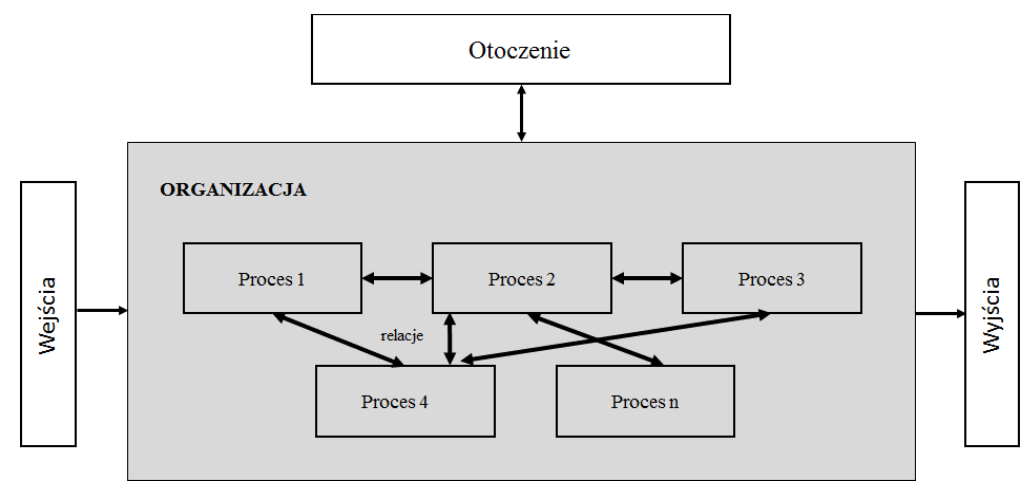

Źródło: A. Dobrowolska, Podejście procesowe w organizacjach zarzq̨dzanych przez jakość, Warszawa 2017, s. 26.

W obrębie zidentyfikowanego systemu procesów organizacji odbywa się transformacja wejść w pożądane wyjścia, a główny proces odpowiedzialny za te przekształcenia należy traktować jako proces biznesowy dostarczający na rynek pożądane przez klienta wartości. Tym samym, proces biznesowy jest kluczowym procesem każdej organizacji.

\footnotetext{
7 Por.: B. Gawin, B. Marcinkowski, Symulacja procesów biznesowych. Standardy BPMS i BPMN w praktyce, Gliwice 2013, s. 37; Sz. Drejewicz, Zrozumieć BPMN. Modelowanie procesów biznesowych, Gliwice 2017, s.10; R. Gabryelczyk, ARIS w modelowaniu procesów biznesu, Warszawa 2006, s. 16.
} 


\section{Założenia modelu SIPOC}

Chcąc zidentyfikować, szczegółowe działania transformacyjne, przyczyniające się do powstania finalnego produktu organizacji, można zastosować model SIPOC. Model ten pozwala na poznanie ogólnej struktury procesu w układzie „wejścia-wyjścia” oraz umożliwia, na wysokim poziomie ogólności, uchwycenie głównych zależności w procesie. Związki te - z punktu widzenia usługowej roli IT w organizacji generują zapotrzebowanie na informację.

SIPOC (Rys. 2) składa się z elementów, których pierwsze litery tworzą akronim modelu:

- Suppliers - Dostawcy

- Inputs - Elementy wejściowe

- Process - Proces

- Outputs - Elementy wyjściowe

- Customers - Odbiorcy

Rys. 2. Model SIPOC

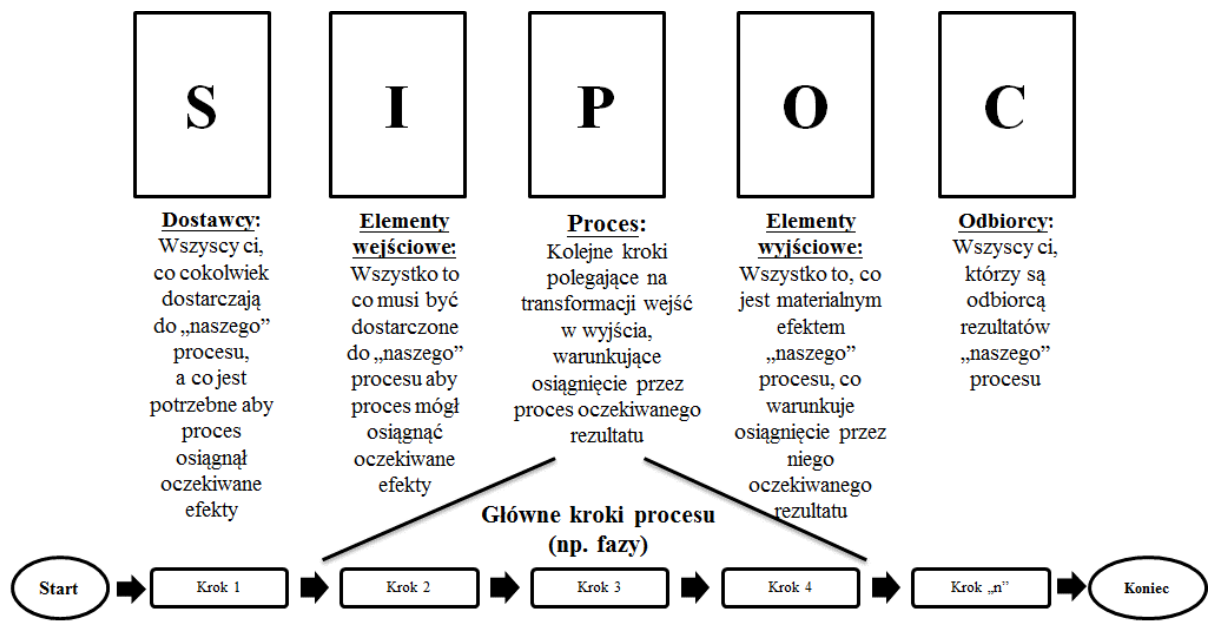

Źródło: Opracowanie własne na podstawie: https://4squareviews.com/2012/11/28 /six-sigma-green-belt-define-phase-sipoc-model/ [dostęp: 13-12-2017]. 
Konrad Michalski - Zastosowanie modelu SIPOC...

Istotna w procesie tworzenia modelu SIPOC jest kolejność „przechodzenia" przez poszczególne jego elementy:

- etap 1: nazwij proces (P),

- etap 2: sprecyzuj początek i koniec procesu, tj. postaw granice procesu i określ jego cel (P),

- etap 3: zdefiniuj i nazwij etapy procesu, tj. zawęź proces do 5-8 głównych kroków (P),

- etap 4: sporządź listę kluczowych wejść i wyjść procesu (I) + (0),

- etap 5: określ dostawców i klientów procesu (S) + (C),

- etap 6 (niewchodzący bezpośrednio w skład modelu): określ sposób pomiaru procesu.

\section{Założenia macierzy odpowiedzialności RACI}

Macierz może identyfikować wszystkie role biorące udział w realizacji procesu, projektu, czy szczegółowych zadań. W kontekście przepływów informacyjnych integrujących - wedle założeń logistyki - przepływy fizyczne w systemie logistycznym, macierz RACI może być zastosowana do identyfikacji interesariuszy kluczowej dla procesu informacji, jak, np. tej o wykonaniu procesu (KPI's). W rozumieniu macierzy RACI, zadania odnoszą się do wygenerowania danej informacji, czyli do tego, aby „pojawiła się” ona w procesie.

Budowę macierzy odpowiedzialności oraz ich definicje (pierwsze litery ról tworzą akronim RACI), przedstawia Rys. 3.

Każdą, zidentyfikowaną w modelu SIPOC, a następnie w macierzy RACI, rolę biznesową (dostawcę, odbiorcę), można uszczegółowić poprzez opis jej powiązań i zależności w procesie, przypisując szczegółowe cele i określając sposób ich pomiaru (Rys. 4). 
Rys. 3. Macierz RACI

\begin{tabular}{|c|c|c|c|c|c|c|c|}
\hline Zadanie / Rola & Rola 1 & Rola 2 & Rola 3 & Rola 4 & Rola 5 & Rola 6 & \multirow{2}{*}{$\begin{array}{c}\text { Responsible } \\
\text { Osoba przypisana do wykonania } \\
\text { czynności. }\end{array}$} \\
\hline Zadanie 1 & $\mathrm{R}$ & & C & & & & \\
\hline & & & & & & & Accountable \\
\hline Zadanie 2 & $\mathrm{R}$ & & A & & $\mathrm{C}$ & & Osoba, która podejmuje ostateczne \\
\hline \multirow{2}{*}{ Zadanie 3} & \multirow{2}{*}{ R } & \multirow{2}{*}{$R$} & \multirow{2}{*}{ I } & \multirow{2}{*}{ A } & & \multirow{2}{*}{ I } & decyje i jestza nie oopowieozalina. \\
\hline & & & & & & & Consulted \\
\hline Zadanie 4 & & & C & & $\mathrm{R}$ & & \multirow{2}{*}{$\begin{array}{c}\text { Osobaz którą należy się } \\
\text { skonsultować przed podjęciem } \\
\text { działań lub decyzi. }\end{array}$} \\
\hline Zadanie 5 & A & & C & 1 & & & \\
\hline Zadanie 6 & & I & C & C & & $\mathrm{R}$ & Informed \\
\hline & & & & & & & $\begin{array}{l}\text { Osoba, korą nalezz poiniormowac } 0 \\
\text { podjetych działaniach lub deczjach. }\end{array}$ \\
\hline
\end{tabular}

Źródło: http://adaptivesag.com/pl/7-architektura-biznesowa-i-korporacyjna.html [dostęp: 13-12-2017].

Rys. 4. Opis ról biznesowych

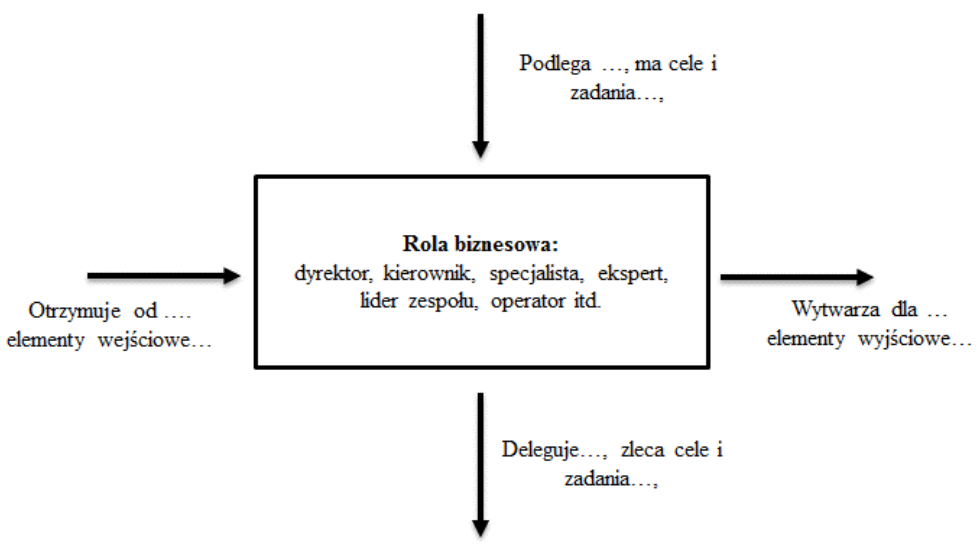

Źródło: Opracowanie własne. 
Konrad Michalski - Zastosowanie modelu SIPOC...

\section{Zastosowanie modelu SIPOC i macierzy RACI $w$ analizie biznesowej operatora logistycznego}

\subsection{Opis procesu biznesowego operatora}

Operator jest jednym z liderów polskiego rynku TSL, dostarczającym kompleksowe usługi logistyczne klientom, spośród których kluczową grupą są producenci samochodów i ich autoryzowane stacje (ASO). Temu segmentowi, operator oferuje, m.in. dostawy materiałów służących do bieżącego montażu samochodów i serwisu w całej Europie - to najważniejsza usługa operatora.

Wartością dostarczaną klientom operatora X jest wsparcie ich działalności wytwórczej i serwisowej, dzięki takim wartościom jak: niezawodność, kompleksowość i terminowość realizowanych dostaw, elastyczność w projektowaniu indywidualnych rozwiązań, budowanie partnerskich relacji i niezakłócona komunikacja w trakcie wszystkich etapów współpracy.

Aby usługi logistyczne operatora spotkały się z zainteresowaniem odbiorców, operator przeprowadza badanie potrzeb rynku. Etap ten kończy się wypracowaniem segmentacji klienta, na podstawie, m.in. informacji na temat zapotrzebowania na usługi w przeszłości, informacji na temat prognoz rozwoju gospodarczego kraju i generowanego w ślad za tym popytu na usługi logistyczne. Uwzględnia się także głos klienta, jego opinie i sugestie, co do kształtu palety usługowej operatora. Odpowiedzialnym za realizację etapu rozpoznania rynku, a w kolejnym etapie, za zaprojektowanie produktów (usług logistycznych), jest Dyrektor ds. Rozwoju Biznesu (BDM - Business Development Manager). Zainteresowanymi segmentacją klienta, $\mathrm{w}$ tym propozycjami wartości dostarczanych klientom przez poszczególne usługi, są przede wszystkim Pion Sprzedaży Usług, kierowany przez Dyrektora Sprzedaży oraz Dział Marketingu i Promocji, działający w strukturach BDM.

Po etapie badania rynku, odpowiednia komórka (Dział Rozwoju Produktów), konstruuje ofertę dla poszczególnych grup klientów, w tym dla segmentu motoryzacyjnego. Aby oferta była kompletna, 
niezbędne są takie elementy, jak: cena przewozu $1 \mathrm{~km}$ dla danego rodzaju dostawy, cena operacji przeładunkowej danego typu, cena standardowej odprawy celnej i ubezpieczenia. Kompletna, a wcześniej zatwierdzona przez Dział Prawny, oferta usługowa operatora zawiera takie elementy jak: cenniki, regulaminy usług, procedury wewnętrzne wraz z projektami przyszłych procesów. Poza klientem, z oferty, będą korzystać wszystkie zainteresowane działy w strukturze organizacyjnej operatora, przede wszystkim operacyjne.

Sprzedaż usług logistycznych operatora polega, w skrócie, na zgłoszeniu przez klienta stałego zapotrzebowania na transport międzynarodowy i podpisaniu, na tej podstawie, umowy długoterminowej ze sprzedawcą usług działającym w ramach Pionu Sprzedaży.

Za realizację usługi dostawy międzynarodowej odpowiada Pion Logistyki, kierowany przez Dyrektora ds. Logistyki. Realizacja usługi jest inicjowana wysłaniem przez klienta bieżącego zlecenia na transport, które, poprzez Dział Obsługi Klienta, trafia do Działu Logistyki. Zlecenie jest potwierdzane i realizowane przez przewoźnika zewnętrznego, na zlecenie Działu Transportu. Realizacja usługi odbywa się we współpracy z ubezpieczycielem i ewentualnie linią lotniczą. Podstawą realizacji usługi jest wybór środka transportu, ubezpieczenia ładunku i odprawy celnej. Usługa ma się zakończyć realizacją zgodnie z wymaganiami klienta.

Satysfakcjonująca obsługa klienta osiągana jest poprzez analizę jego głosu klienta oraz dzięki na bieżąco dostarczanym informacjom o opóźnieniach i innych zakłóceniach w realizacji dostawy. Serwis jest koordynowany przez Dział Obsługi Klienta, który na bieżąco zleca, m.in. niezaplanowane dostawy też uzupełniające, po sygnale klienta o stwierdzonych brakach. Realizacja fazy potransakcyjnej przynosi też analizę wykonania procesów obsługowych i zestawienie niezbędnych działań związanych z usprawnianiem czy udoskonalaniem procesów, za co odpowiedzialny jest Ekspert ds. doskonalenia procesów, podległy Zarządowi. 
Konrad Michalski - Zastosowanie modelu SIPOC...

\subsection{Model SIPOC dla procesu biznesowego}

Dzięki ogólnej mapie procesów oraz opisowi procesu biznesowego, uszczegółowionemu w toku dyskusji z uczestnikami procesu, pozyskano wiedzę o powiązaniach między procesami operatora. Stworzono model (Rys. 5) dla procesu biznesowego, łączącego aktywności prowadzące do dostarczenia wartości odbiorcom usług. Model tworzono zgodnie z przyjętą kolejnością, dla każdego z kroków procesu, począwszy od pierwszego.

Rys. 5. Model SIPOC dla procesu biznesowego operatora logistycznego X

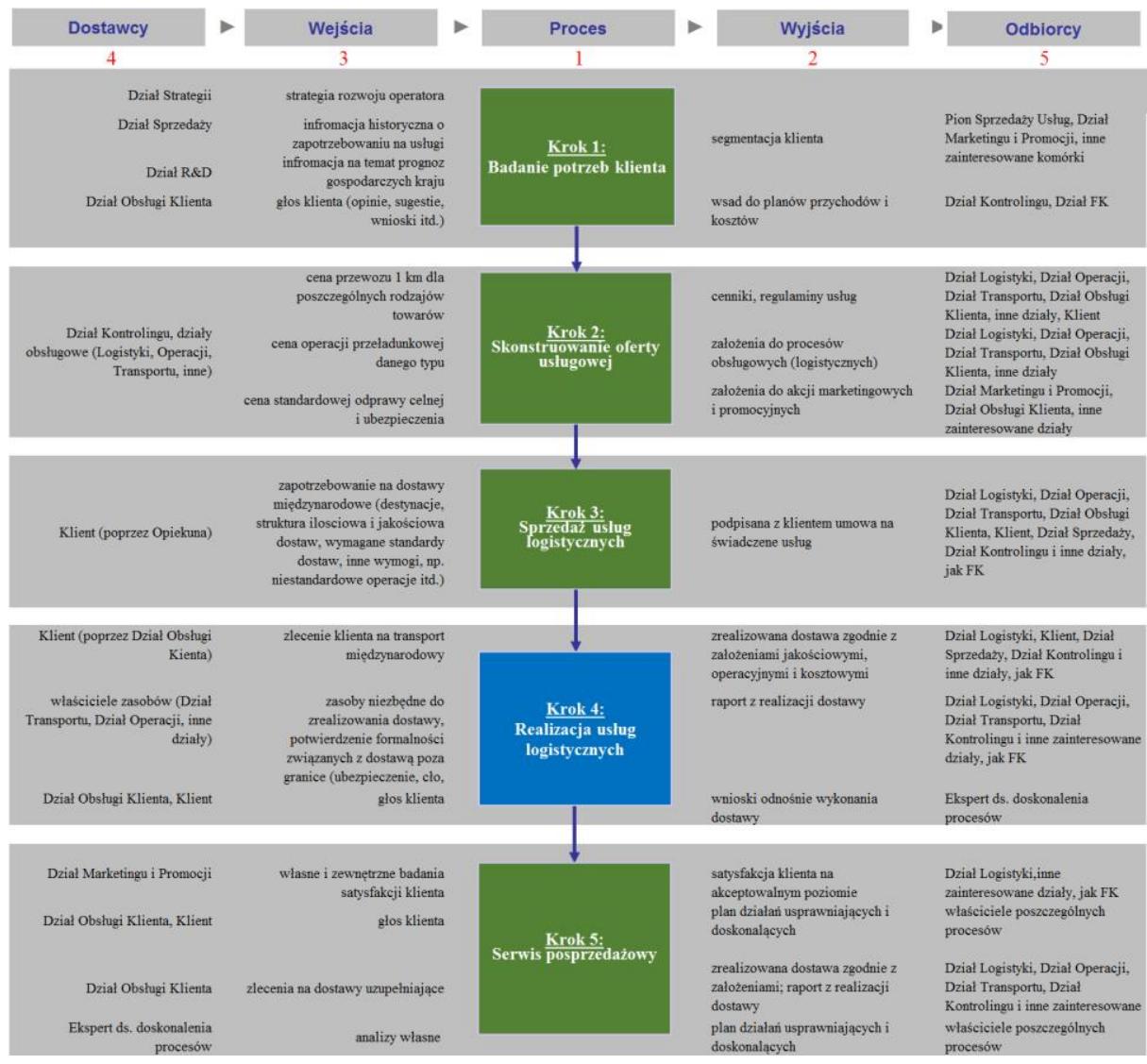

Źródło: Opracowanie własne. 


\subsection{Proces realizacji usługi dostawy międzynarodowej}

W procesie biznesowym operatora $\mathrm{X}$, kluczową rolę odgrywa proces logistyczny, oparty na fizycznej dostawie części do miejsc ich przeznaczenia. Do opisu tego procesu (Rys. 6) posłużono się standardową notacją do modelowania procesów biznesowych (Tabela 1).

Tabela 1. Standardowe symbole stosowane do sporządzania map procesów i ich charakterystyka

\begin{tabular}{|c|c|c|}
\hline Symbol & Nazwa symbolu & Charakterystyka symbolu \\
\hline & $\begin{array}{l}\text { Początek (trigger) lub koniec } \\
\text { (termination) procesu }\end{array}$ & $\begin{array}{l}\text { Symbol umieszcza się na mapie w celu zasygnalizowania rozpoczęcia lub zakończenia } \\
\text { danego procesu; w opisie procesu(np. słownej legendzie odnoszacej siẹ do każdej } \\
\text { czynności (działania) należy podać zdarzenia rozpoczynające i konczące proces. }\end{array}$ \\
\hline & Czynność (dzialanie) & $\begin{array}{l}\text { Symbol wskazuje na dzialanie (operacje) wykonywane w procesie wraz odpowiednim } \\
\text { kodem odpowiadającym czynności lub wstawionym w polu opisem czynności np. } \\
\text { „wystawienie faktury", „przyjęcie zlecenia od klienta" }\end{array}$ \\
\hline & $\begin{array}{l}\text { Kierunek dzialania lub } \\
\text { sekwencji dzialania }\end{array}$ & $\begin{array}{l}\text { Symbol wskazuje na mapie kierunek przebiegu procesu od działania poprzedzającego do } \\
\text { działania nastẹpnego, np. przyjęcie zamówienia", a nastepnie „skierowanie do realizacji” }\end{array}$ \\
\hline & Decyzja & $\begin{array}{l}\text { Symbol wskazuje miejsca i operacje, w których są podejmowane decyzje o wyborze } \\
\text { wariantu dalszego przebiegu procesu, np. „czy konieczne jest zamówienie transportu?": } \\
\text { "TAK" oznacza przejście do procesu transportu, „NIE" oznacza klient sam odbiera } \\
\text { produkt }\end{array}$ \\
\hline & $\begin{array}{l}\text { Punkt styku } z \text { innym procesem } \\
\text { lub odwolanie do innego procesu }\end{array}$ & $\begin{array}{l}\text { Symbol oznacza punkt styku dwóch procesów, np. symbol „proces obsługiklienta" } \\
\text { wskazuje, że w tym momencie efekt procesu produkcji (np. gotowy produkt np. } \\
\text { odkurzacz), pojawia się jako element wejściowy w procesie obsługiklienta }\end{array}$ \\
\hline & Zasilenie lub rezultat & $\begin{array}{l}\text { Symbol oznacza zasilenie procesulub rezultat jego działania; symbol może opisywać } \\
\text { miejsce powstawania lub modyfikacji dokumentu. }\end{array}$ \\
\hline
\end{tabular}

Źródło: P. Grajewski, Procesowe zarządzanie organizacja, Warszawa 2012, s. 51. 
Konrad Michalski - Zastosowanie modelu SIPOC...

Rys. 6. Proces realizacji usługi dostawy międzynarodowej operatora logistycznego X

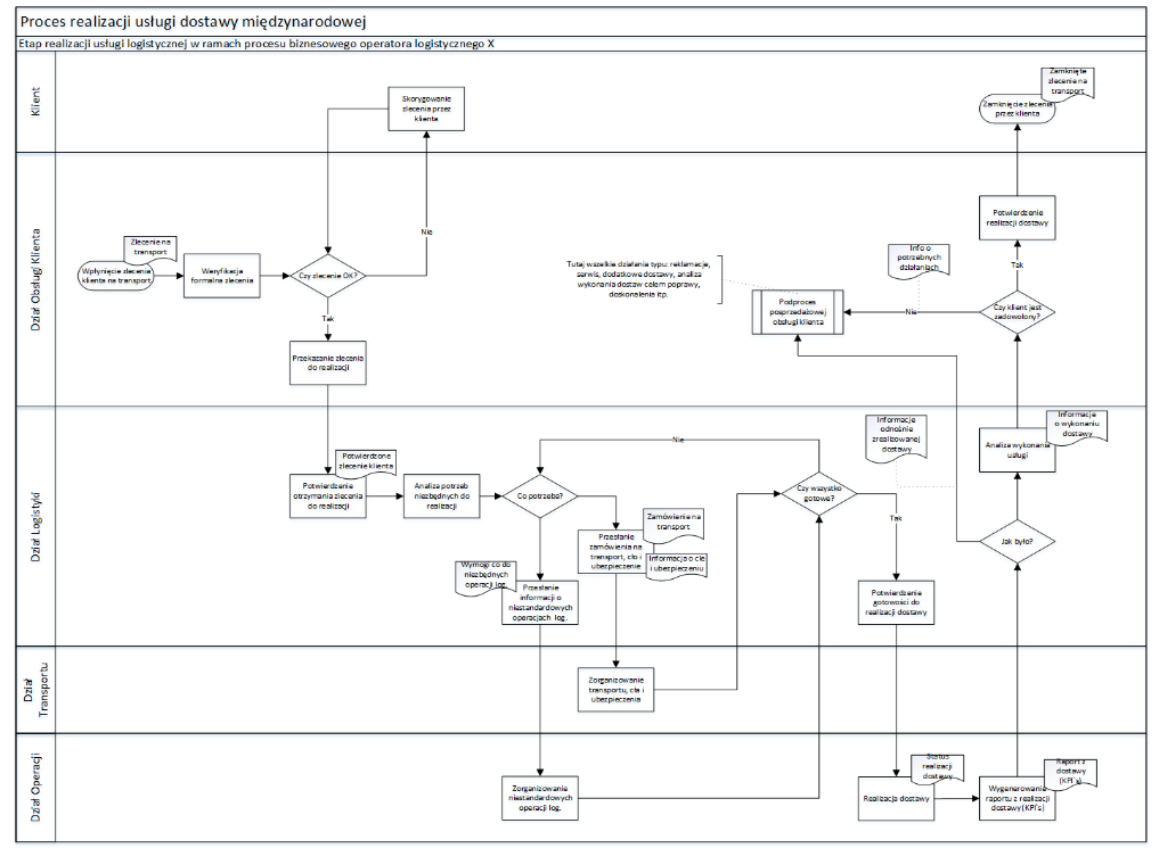

Źródło: opracowanie własne.

\subsection{Kluczowe role i odpowiedzialności w procesie biznesowym operatora}

W rozpatrywanym przypadku operatora, macierz RACI wykorzystano do identyfikacji ról i ich odpowiedzialności za realizację zadań dotyczących wygenerowania, umożliwienia wygenerowania lub udostępnienia informacji związanej z realizacją procesu biznesowego. Zadania znajdujące się w macierzy dotyczą kluczowej informacji mającej charakter integrujący i koordynujący przepływ strumienia pracy niezbędnego do obsługi klienta w trakcie wszystkich faz procesu biznesowego. Zidentyfikowana informacja, wraz z jej „udziałowcami”, ma w założeniu stanowić minimalny zakres przepływów informacyjnych operatora, w sposób kompleksowy obsługiwanych przez jedno rozwiązanie infor- 
matyczne, mieszczące się w klasie ERP8. Wdrożenie tego systemu jest strategicznym celem operatora, gdyż dzisiaj posiada on wiele, rozproszonych rozwiązań, trudnych do integracji i koordynacji przepływu informacji na poziomie wsparcia wykonywanych zadań, w tym operacji logistycznych.

Rys. 7. Macierz RACI dla zadań związanych z kluczową informacją dla procesu biznesowego operatora logistycznego $\mathrm{X}$

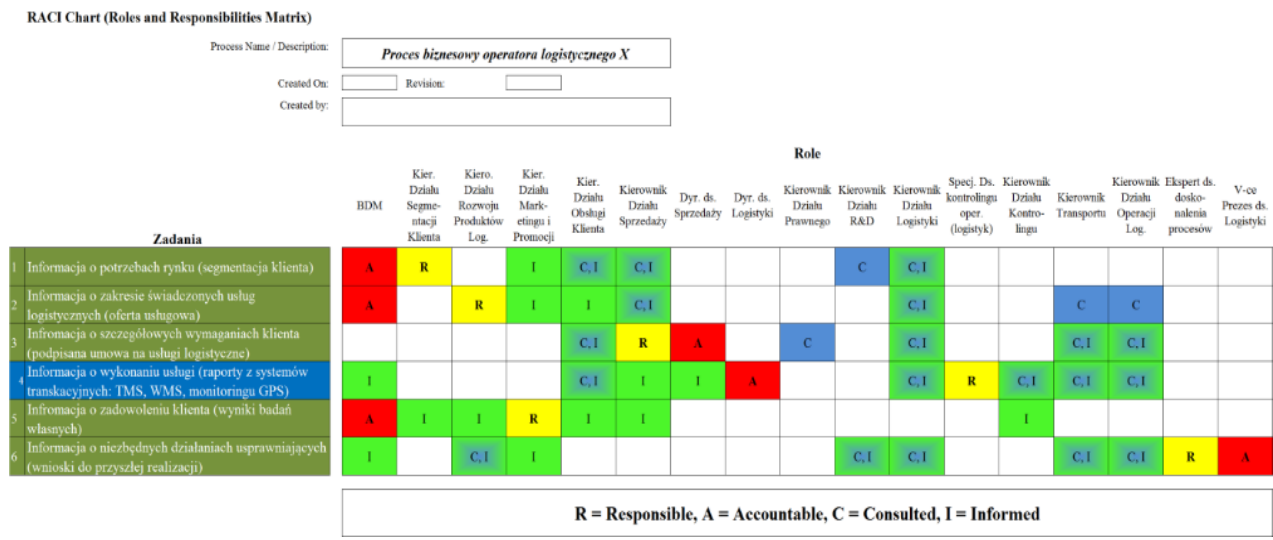

Źródło: Opracowanie własne z wykorzystaniem wzorca ze strony http://www.racichart.org [dostęp: 14-12-2017].

${ }^{8}$ ERP (Enterprise Resource Planning) - klasa systemów IT wspomagających zarządzanie przedsiębiorstwem lub współdziałanie współpracujących ze sobą przedsiębiorstw poprzez gromadzenie danych oraz umożliwienie realizacji operacji na zebranych danych. Wspomaganie ERP obejmuje wszystkie lub część szczebli zarządzania, ułatwiając optymalizację wykorzystana i zasobów oraz zachodzących w przedsiębiorstwie procesów. A. Szymonik, Informatyka dla potrzeb logistyka(i), Warszawa 2015, s. 90-91. 
Konrad Michalski - Zastosowanie modelu SIPOC...

\section{Wnioski}

Zaprezentowane w artykule podejście do analizy biznesowej, opiera się na kilku etapach, tworzących pewien proces poznawania organizacji, jej celów i procesów, na których realizacji oparte jest ich osiąganie, $\mathrm{tj}$.:

- stworzenie mapy procesów pozwala na uchwycenie „z lotu ptaka” systemu organizacji i jej powiązań z otoczeniem bliższym i dalszym, w tym przede wszystkim z partnerami i klientami konsumującymi produkty organizacji; ten krok pozwala na nabycie podstawowej wiedzy o miejscu i roli organizacji, która powinna być traktowana jak klient, mający swoje oczekiwania i cele do realizacji - w tym znaczeniu mapa procesów jest wstępem do dalszych działań w obszarze analizy biznesowej,

- wykorzystanie modelu SIPOC ${ }^{9}$ umożliwia wyspecyfikowanie wszystkich kluczowych elementów w organizacji, na których oparta jest transformacja wejść w wyjścia, w tym, w wartości oczekiwane przez odbiorców produktów końcowych organizacji; model SIPOC pozwala, z jednej strony, na identyfikację wszystkich nakładów i kosztów, jakie organizacji musi ponosić, aby dostarczać swoje produkty na rynek, z drugiej natomiast, umożliwia spojrzenie na wszystkie nakłady i koszty z punktu widzenia zasadności ich ponoszenia, gdzie przyczynianie się do podnoszenia dostarczanej wartości jest nadrzędnym kryterium oceny,

- skonstruowanie schematu przebiegu procesu logistycznego pozwala na pogłębienie wiedzy o szczegółowych działaniach związanych $\mathrm{z}$ realizacją kluczowego procesu wytwórczego - w rozpatrywanym przypadku, logistycznego - który dla innych procesów tego typu, stanowić może wzorzec działania, wymagający pewnego minimum informacyjnego, który docelowo zapewnia, system IT,

\footnotetext{
${ }^{9}$ Podobnie model SIPOC można zastosować w każdym innym przedsiębiorstwie, np. produkcyjnym. Przemawia to za uniwersalizmem tej metody. Zob. J. Dyczkowska, Projektowanie procesów logistycznych w przedsiębiorstwie produkcyjnym - przesłanki, „Logistyka” 2014, nr. 4, s. 1784 (CD).
} 
- macierz RACI, po identyfikacji kluczowych zadań związanych z niezbędnym zaopatrzeniem informacyjnym organizacji, pozwala na analizę powiązań pomiędzy uczestnikami przepływów informacyjnych i ich poprawności z punktu widzenia sprawności, skuteczności i efektywności całości procesu biznesowego; role zidentyfikowane w macierzy stanowią jednocześnie zręby założeń przyszłych użytkowników wdrażanego systemu IT.

Jednocześnie, zaprezentowane $w$ artykule podejście, stanowić może jedynie punkt wyjścia do dalszych prac przygotowawczych i planistycznych, obejmujących, m.in.:

- zaprojektowanie działania planowanego do wdrożenia systemu, w tym określenie użytkowników i realizowanych przez nich szczegółowych zadań, a wszystko $\mathrm{w}$ języku zrozumiałym dla informatyków, w tym programistów,

- zaplanowanie wdrożenia $\mathrm{w}$ organizacji systemu, zapewniającego maksymalizację korzyści $\mathrm{z}$ jego wdrożenia, w tym niezbędnych zmian w obszarze działania organizacji i jej procesów - nie ma bowiem w praktyce wdrożenia w 100\% uwzględniającego stan obecny („as-is”), potrzebna jest także zmiana u klienta (organizacji), a więc wymodelowanie optymalnej sytuacji „as-if” (organizacja pracy, struktura organizacyjna, procesy, itd. po wdrożeniu).

\section{Bibliografia:}

Chaberek M., Logistyka informacji zarządczej w kontrolingu przedsiębiorstwa, Wyd. UG, Gdańsk 2001.

Drejewicz Sz., Zrozumieć BPMN. Modelowanie procesów biznesowych, Wyd. Helion, Gliwice 2017.

Davenport T.H., Process Innovation: Reengineering Work through Information Technology, Harvard Business School Press, Boston 1993.

Dobrowolska A., Podejście procesowe w organizacjach zarządzanych przez jakość, Wyd. Poltext, Warszawa 2017.

Dyczkowska J., Projektowanie procesów logistycznych w przedsiębiorstwie produkcyjnym - przesłanki, „Logistyka” 2014, nr 4. 
Konrad Michalski - Zastosowanie modelu SIPOC...

Gabryelczyk R., ARIS w modelowaniu procesów biznesu, Wyd. Difin, Warszawa 2006.

Gawin B., Marcinkowski B., Symulacja procesów biznesowych. Standardy BPMS i BPMN w praktyce, Wyd. Helion, Gliwice 2013.

Grajewski P., Procesowe zarządzanie organizacja, Wyd. PWE, Warszawa 2012.

Hammer M., Champy J., Reeingeering $w$ przedsiębiorstwie, Neuman Management Institute, Warszawa 1996.

Skrzypek E., Jakość i efektywność, Wyd. UMCS, Lublin 2002.

Szymonik A., Informatyka dla potrzeb logistyka(i), Wyd. Difin, Warszawa 2015. Żeliński J., Analiza biznesowa. Praktyczne modelowanie organizacji, Wyd. Helion, Gliwice 2017.

\section{Zasoby internetowe:}

http://adaptivesag.com/pl/7-architektura-biznesowa-i-korporacyjna.html [dostęp: 13-12-2017].

http://www.racichart.org [dostęp: 14-12-2017].

https://4squareviews.com/2012/11/28/six-sigma-green-belt-define-phasesipoc-model/ [dostęp: 13-12-2017]. 